\begin{tabular}{|c|c|}
\hline \multirow{3}{*}{ 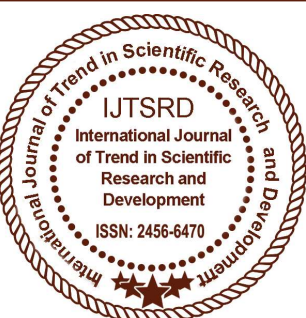 } & $\begin{array}{l}\text { International Journal of Trend in Scientific } \\
\text { Research and Development (IJTSRD) }\end{array}$ \\
\hline & International Open Access Journal \\
\hline & ISSN No: 2456 - 6470 | www.ijtsrd.com | Volume - 2 | Issue - 5 \\
\hline
\end{tabular}

\title{
Different Module Integrated Converters for PV Systems A Review
}

\author{
Ms. Diksha A. Kamble ${ }^{1}$, Dr. S. B. Chavan ${ }^{2}$ \\ ${ }^{1} \mathrm{M}$. Tech. Student, ${ }^{2}$ Assistant Professor \\ Department of Technology, Shivaji University, Kolhapur, Maharashtra, India
}

\begin{abstract}
In this paper literature review of PV module integrated converters has been conducted. Many times it is necessary to boost the PV voltage, further the size of power processing circuitry should be as small as possible. Considering this many researchers have worked on development of module integrated converters, in which converters are fitted in PV module. The PV output is boosted to desire level by using suitable MPPT techniques. Converters with high efficiency, higher voltage gain, and cascaded topologies can be designed for this purpose.
\end{abstract}

Keywords: PV module, Galvanic isolated resonant converter, VDR, Soft switching

\section{INTRODUCTION}

Many times it is desirable to boost the PV voltage for further power processing. PV panels should provide maximum output voltage. Module integrated converters with voltage boost capacity or converters with voltage multiplying ability can be a good choice for this. Nowadays much research is going on implementation of converter topologies like resonant converters, isolated converters and many more topologies for efficiency or reliability improvements etc. This paper presents evaluations among the most usual maximum power point tracking (MPPT) techniques [10], doing meaningful comparisons with respect to the amount of energy extracted from the photovoltaic panel with factors like power, dynamic response, ripple voltage etc. Due to the growing demand of electricity, the limited stock and rising prices of conventional sources photovoltaic (PV) energy becomes a promising and alternative as it is omnipresent freely available in environment and it has less operational and maintenance cost so efficient MPPT technique is necessary.

\section{MODULE INTEGRATED CONVERTERS}

The series resonant push-pull converter for PV application with high performance has been designed [1].Due to growing demand on electricity, the limited stock and rising prices of conventional source PV energy becomes a promising and alternative as it is omnipresent freely available in environment and its less operation and maintenance cost also less so MPPT technique is necessary.

A soft switching push-pull converter for PV application has been developed [2]. Due to hard switched converter efficiency lower due to higher losses and to step-up voltage higher turn ratio is required .By using soft switching technique at power switch side loss can be minimized and higher efficiency can be obtained.

Design dc-dc converter for evaluation of PV panel integrated concepts [3].Some power has reduced when string current is reduced of shaded panel so by using this converter power can be increases at each panel. This converter Is most promising for getting higher power density and efficiency.

Very low profile integrated PV module has developed [4].Distributed maximum power point tracking (DMPPT) Technique is used for this PV module and high frequency, low profile, high step-up are required but its effective cost and reliable for improving power density of PV module .This module is to achieve high efficiency conversion and operation of reliable converter.

Single phase integrated PV module with DC link configuration has implemented [5].In PV module market, the building integrated PV panel is strongest 
part for module level application. By using half bridge, full bridge, push-pull, buck boost converters this topology has been developed for module integrated converter. The module integrated converter is better for this topology.

Recovery snubber module for PV module is implemented [6].By using snubber recovery technique leakage energy problem can be reduced at low level voltage for given power. But one problem is that transformer leakage inductance energy.

Push-pull converter based on microcontroller for PV application with high frequency has designed [7].In literature, different PV module converters options can be found. This type of topologies has high voltage conversion ratio and low ripple current. It is easy to drive but these converters are the switches rating must be two times of the input voltage.

Flyback current fed PV module has designed [8].In many converters, more number of diodes are connected to secondary side but in this paper, by using current fed technique reducing the number of diodes for better output. The converter which decreasing the number of diodes at output side so it can be continuous conduction mode.

Better and effective control strategy for improving performance of a current fed converter [9].By using this type of module they are avoiding the magnetic flux saturation and winding of transformer of that converter. It is more effective magnetic design as well as design power switches of converter at low switching stress. This review focused on design and implementation and performance analysis of converter for module level power electronics application.

High efficiency LLCC type PV module has implemented for power electronics application [10].In designing of LLCC converter one challenge is derived the transformer inductor device by considering the geometry and high efficiency can be obtained. This integrated module is clamped to fixed voltage by using maximum power point tracking technique (MPPPT) and maximum output current is obtained.

Due to the zero voltage switching and zero current switching the current fed resonant converter is designed [11]. This converter which inductor and capacitor operates at two times of switching frequency and also unregulated the low to high voltage conversion. The transformer is magnetize the current and drain source capacitor so min switch operates at zero voltage switching and output diodes and main switches are operated by zero current switching.

A soft switched PV module has been developed [12].Due to the high step up ratio and high frequency transformer the converter is to suitable for low voltage power electronic application. By using soft switching technique decreases the switching losses and also decreases the turn ratio of the transformer.

Developed algorithm detects the abnormalities, finds their root causes and also predicts the possibility of potential health problems for the circuit breaker trip coil/assembly. Additionally, the monitoring architecture also allows remote access of data for engineering access.

\section{III.CONCLUSION:}

An overview of integrated galvanic push-pull converter in PV module is discussed. For isolation of transformer different switching techniques are used also solved damage of power switches. The advantage of using dc-dc converter is two folds first is the efficiency .In ideal condition, elements in the circuits, such as inductor, capacitor, switches and diodes, don't consume any energy. So ideal efficiency is 100 $\%$. In practice the efficiency of dc-dc converter will exceed $90 \%$ which is very high for power transformation.

\section{ACKNOWLEDGEMENT:}

Authors are thankful to Shivaji University, Department of Technology, Kolhapur, India (Maharashtra), for providing necessary facilities for completion of this review.

\section{REFERENCES:}

1. Dmitri Vinnikov, Andrii Chub, Elizaveta Liivikand Indrek Roasto, "High-Performance Quasi-Z-Source Series Resonant DC-DC Converter for Photovoltaic Module-Level Power Electronics Applications," IEEE transactions on power electronics, vol. 32, no. 5, may 2017.

2. Y.-H. Kim, S.-C. Shin, J.-H. Lee, Y.-C. Jung, and C.-Y. Won, "Soft switching current-fed push-pull converter for $250-\mathrm{W}$ AC module applications," IEEE trans. power electron. vol. 29, no. 2, pp. 863-872, feb. 2014. 
3. Matthias Kasper, Dominik Bortis, and Johann W. Kolar, "Classification and Comparative Evaluation of PV Panel-Integrated DC-DC Converter Concepts"IEEE Transactions on Power Electronics, Volume: 29, Issue: 5, 2014.

4. Milos Acanski, Jelena and PopovicGerber, "Design of a flexible very low profile high step-up PV module integrated converter", IEEE Energy Conversion Congress and Exposition (ECCE)Year: 2012

5. Quan Liand Peter Wolfs, "A Review of the Single Phase Photovoltaic Module Integrated Converter Topologies with Three Different DC Link Configurations"IEEE transactions on power electronics, vol. 23, no. 3, may 2008.

6. T. C. Lim B. W. Williams S. J. Finney H. B. Zhang C. Croser "Energy recovery snubber circuit for a dc-dcpush-pull converter" published in IET power electronics

7. Sharulnizam Mohd Mukhtar "A High Efficiency Microcontroller-Based Step-up Push-Pull DC-DC Converter for PV Inverter" IEEE international conference on power and energy 2010.
8. D. A. Ruiz-Caballero and I. Barbi, "A new flyback-current-fed push-pull DC-DC converter," IEEE Trans. Power Electron., vol. 14, no. 5, pp. 1056-1064, Nov. 1999.

9. L. V. Hartmann, M. B. R. Correa, and A. M. N. Lima, "A simple and effective control strategy for improved operation of a current-fed push pull converter," in Proc. IEEE. Energy Convers. Congr. Expo. Sep. 2010, pp. 1098-1103.

10. Christian P. Dick, Furkan K. Titiz, Rik W. De Doncker, "A High-Efficient LLCC Series-Parallel Resonant Converter" IEEE Applied Power Electronics Conference and Exposition (APEC) 2010.

11. C.-L. Chu C.-H. Li, "Analysis and design of a current-fedzero-voltage-switching and zerocurrent-switching CL-resonant push-pull dc-dc converter", IET Power Electronics Sep. 2008.

12. K. Abarna1, S. Divya1 and P. Raja Rajeswari, "soft-switching current-fed push-pull converter for PV application", ARPN Journal of Engineering and Applied sciences vol. 10, no. 8, May 2015. 